\title{
Tebriz Üniversitelerindeki Öğretim Üyelerinin Bilgi Arama Davranışları ve Bilgi-illetişim Teknolojilerinin Bu Davranışlar Üzerindeki Etkisi
}

\author{
Information Seeking Behaviors of Faculty Members \\ of Universities in Tabriz and Impact of Information- \\ Communication Technologies on this Behavior
}

Torab NAJJARI*

\begin{abstract}
Öz
Bilişim teknolojileri ile dijital ortamda üretilen ve kullanıma sunulan bilgi kaynakları, üniversitelerde çalışan öğretim üyelerinin bilgi arama, erişim ve kullanma davranışlarını büyük oranda değiştirmiştir. Öğretim üyelerinin değişen bu davranışları, üniversite kütüphanelerinin bilgi hizmetlerini de etkilemekte ve şekillendirmektedir. Bu çalışmada, Tebriz Üniversitesi, Azerbaycan Terbiyet-i Moellem Üniversitesi, Tebriz Sağlık Bilimleri Üniversitesi, İslami Azat Üniversitesi ve Endüstri Sehend Üniversitesi'nden 1.907 öğretim elemanının bilgi arama davranışı incelenmiştir. Araştırma sonucunda, bilişim teknolojilerinin Tebriz üniversitelerindeki öğretim elemanlarının bilgi arama davranışları ile üniversite kütüphanelerinin bilgi hizmetleri politikalarını önemli ölçüde etkilediği tespit edilmiştir.
\end{abstract}

Anahtar sözcükler: Bilgi arama davranışı, Üniversite kütüphaneleri, Bilgi teknolojileri, Illetişim teknolojileri, Iran

\begin{abstract}
Information technologies and the information resources produced and presented in digital formats have considerably changed the information-seeking, information-accessibility and information-use behavior of faculty at universities. These changing behaviors of faculty has affected and shaped the information services of university libraries. In this study, data about the information-seeking behavior of 1907 teaching staff from different universities (Tabriz University, Azerbaijan Tarbiyat Moallem University, Tabriz Medical Sciences University, Islamic Azad University, Sahand Industrial University) have been gathered and examined. The findings show that information technologies have had a considerable impact on the information-seeking behavior and information literacy habits of the teaching staff at the universities in Tabriz as well as the collection of information, collection development and the policies of information services at the information centers of these universities.
\end{abstract}

Keywords: Information seeking behaviour, University libraries, Information technology, Communications technology, Iran

* Doktora Öğrencisi, Ankara Üniversitesi, Sosyal Bilimler Enstitüsü Bilgi ve Belge Yönetimi Ana Bilim Dalı, Sıhhiye/ Ankara. (najjari2009@yahoo.com) 


\section{Giriş}

Bilgi arama davranışı, etkili ve kaliteli bir problem çözme sürecinin önemli bir kısmını oluşturmaktadır. Bu bağlamda pek çok bilgi arama davranışı modeli ortaya çıkmıştır ve bilgi arama modellerinin çoğu bilgi arama davranışını bireysel bir eylem olarak tanımlamışlardır (Wilson, 1999, s.264). Şüphesiz bir ülkenin gelişmesi ve modernleşmesi, o ülkenin bilim adamlarının, yöneticilerinin, öğretim üyelerinin ve her sektörde çalışanlarının gayretli çalışmalarıyla birlikte, yine o ülkenin bilgi üretme, bilgi elde etme, bilgiyi paylaşma ve kullanma alışkanlığına da bağlıdır. Günümüz dünyasında her ülkenin ve toplumun teknolojik, ekonomik, siyasi yapısını ve yönünü, o ülkelerin yöneticileriyle birlikte bilim adamları da belirleyebilmektedir.

Dün olduğu gibi bugün de, toplumların gelişmesini etkileyen etkenler arasında bilim adamlarının bilgi üretmesi, derlemesi, düzenlemesi, üretilen ve elde edilen bilginin paylaşımının sağlanması yer almaktadır. Geçmişten günümüze ortaya çıkan bilgi kaynaklarının varlığı, toplumun ve özellikle o toplumda yaşayan bilim adamlarının bilgiye ve bilime önem verdiklerini göstermektedir. Özellikle batı dünyası ülkeleri, bilgi üretme etkinliğiyle bilgiyi toplayarak, derleyerek, depolayarak, paylaşarak, bilgi tabanlı yeni yatırımlar yaparak ve bilim adamlarının da kitap, rapor, makale, tez, veri tabanları ve diğer bilgi kaynaklarına erişimlerini sağlayarak ülkelerinin ve bilimin ilerlemesine önemli katkılarda bulunmaktadırlar.

Bilgi üretme, derleme, depolama, koruma ve paylaşma gibi süreçler hızlı bir şekilde değişmektedir. Gutenberg'in 1450 yılında ürettiği matbaa ile başlayan ve sanayi devrimi ile de büyük bir ivme kazanan bilgi teknolojilerindeki yenilikler günümüzde artarak devam etmektedir. Baskı tekniğinin gelişmesi o dönemde kütüphanelerin değişimine ve gelişimine neden olurken, günümüzde de bilgi ve iletişim teknolojileri, bilgi merkezlerinin gelişimlerini ve hizmetlerinin niteliğini şekillendirmektedir.

Yaşamakta olduğumuz çağ "bilgi çağı" olarak adlandırılmaktadır. Bu çağda bilgi ve iletişim teknolojileri, geleneksel kütüphanelerin yapısını değiştirerek kullanıcıları ve onların bilgi arama davranışlarını da büyük oranda etkilemektedir. Kütüphanelerin kendi rollerini koruyabilmesi ve etkinliklerini istenen şekilde sürdürebilmesi, bilgi kaynaklarının yanı sıra kullanıcıların bilgi arama davranışlarını da dikkate almasına bağlıdır. Modern kütüphanelerin en önemli misyonu, kullanıcıların bilgi gereksinimlerini zamanında, istenilen ve onları tatmin edecek biçimde uygun, hızlı ve güvenli bir şekilde karşılamaktır. Üniversite kütüphanelerinin misyonlarını yerine getirip getirmediğinin önemli göstergelerinden biri, kullanıcılarının bilgi arama davranışlarını belirleyerek onların bilgi gereksinimlerini karşılayıp karşılamama durumudur.

Bütün kütüphanelerin temel amacı, kullanıcıların bilgiye erişim sürecini hızlandırmak ve gereksinim duydukları bilgiyi istenilen zamanda sunmaktır. Kullanıcıların bilgi gereksinimlerinin, bilgiarama davranışlarının, sunulan hizmetlerdekitatmin düzeylerinin 
belirlenmesi ve bu doğrultuda bilgi hizmetlerinin kullanıı merkezli olarak planlanması tüm bilgi merkezleri veya sistemleri için gereklidir. Her kütüphanenin kendine ait bir kullanıcı grubu vardır. Üniversite kütüphanelerinin önemli kullanıc gruplarından birisi de öğretim üyeleridir.

Bu çalışmada, Tebriz'deki üniversitelerde görevli öğretim üyelerinin bilgi arama davranışları incelenmiş, bu kullanıcı grubunun bilgi gereksinimlerinin üniversite kütüphaneleri tarafından karşılanıp karşılanmadığı durumu ortaya konulmuş, kütüphaneler tarafından verilen hizmetlerin geliştirilmesine yönelik önerilere yer verilmiştir.

\section{Bilgi Arama Davranışı}

İnsan davranışlarının bilimsel olarak incelenmesi ve davranışın inceleme teknikleri oldukça yenidir. Bireylerin davranışları, davranışlarının nedenleri, amaçları, şekilleri ve özellikleri çeşitli disiplinler tarafından özellikle de "davranış bilimleri" başlığı altında incelenmektedir (Soydan, 1979, s.15).

İnsanın davranışı çok çeşitli biyolojik, psikolojik ve sosyolojik olaylara ve nedenlere bağılır. Belirli bir durumda meydana gelen davranışın açıklanması çeşitli şekillerde yapılabilmektedir. Davranışı açıklamak için yapılan araştırmalarda kullanılan metotlar çeşitlidir. Bütün metotlar, bir bütünlük içinde insan davranışlarının daha iyi anlaşııması amacını taşımaktadır (Baysal ve Tekarslan, 2004, s.37).

Davranış bir insanın gözlenebilir, ölçülebilir, yinelenebilir ve anlatılabilir bilinçli eylemleri ve etkinliklerdir (Başaran, 2000, s.11). Diğer bir deyişle, davranış bir insanın değişik çevre şartlarına ve çevredeki değişmelere kendisini uydurabilme yollarından biridir. Insanın hareketlerinin hepsi, sinir sistemi faaliyetleri, sinirsel ve kassal bağlantılılar açısından incelenebilir. Davranış, "açık veya örtülü nitelikte olabilecek bir davranımlar zincirinin belli bir sıra ve uyarlık (armoni) içinde sunulmuş hali"dir (Arı, Üre ve Yılmaz, 1999, s.169). Davranış kavramı, öncelikle insanın tek tek veya toplu olarak gösterdiği faaliyetler olarak da tanımlanabilir. Bireyler, aynı fabrikada üretilen bir ürün değildir, her bireyin veya insanın özellikleri diğerinden farklıdır. Böyle olunca bütün bireyleri standart bir üretim faktörü olarak görülmesi mümkün değildir. Bireylerin farklı olmasının temeli psikolojiye dayanmaktadır. Her birey, diğer bireylerden farklıdır ve zaman geçtikçe bireyler kendilerine özgü bir özelliğe ve davranışa sahip olurlar. Bu farklılıktan ötürü bireylerin temel analiz birimi olarak ele alınması gerekmektedir. Birey sadece bir biyolojik ve canlı varlık olmakla birlikte, karşılaştığı değişik durumlarda farkı davranışlarda bulunan ve psikolojik, kültürel ve sosyal yönü ağır basan bir varlıktır. Bireyin her davranışı bir nedene dayanır ve bu davranışının temelinde de başka nedenler vardır. Birey bazı olaylar karşısında tepki gösterirken, bazılarına karşı tepkisiz kalabilir (Erdoğan, 1994, s.2). 
Bazı davranışlar kolaylıkla bazıları da zorlukla açıklanabilirken bazen hiç açıklanamayabilir. Freud, insan davranışlarının nedenlerinin bilinç, bilinçaltı ve bilinçdışı olmak üzere üç ayrı bölümden oluştuğunu ileri sürer. Bu yaklaşıma "Topografik Kuram" denir (Yanbastı, 1996, s.1).

Kütüphaneler ve bilgibilimle ilgili araştırma verilerinin büyük bir bölümü kullanıcı çalışmalarına odaklanmaktadır. Bu durum, Library Literature, Library and Information Science Abstracts ve Online Computer Library Center'daki birçok bibliyografik veri tabanı ile doğrulanmıştır. Bilgi arama davranışının modellemesi, son yıllarda araştırmacıların merak konusu olmuştur (Ocholla, 1999, s.128).

Bilgi arama davranışı, bir süreç olarak insanın bilgiye gereksinim duyduğu andan başlayıp, bilgiyi elde edip kullanması aşamasına kadar devam eder. Diğer bir deyişle bilgi arama davranışı, bir takım gereksinimleri karşılama ve amaçlara ulaşma yöntemidir. Bir bireyin bilgi arama yöntemi (bir gazeteden veya bir kütüphaneden bilgi araması gibi), elle yapılan bilgi sistemleri ile veya bilgisayar ve iletişim sistemlerine dayalı dünya çapında yapılan (web gibi) davranışları kapsamaktadır (Wilson, 2000, s. 49). Kısaca bilgi arama davranışı, insan gereksinimlerinin karşılanması amacıyla bilgiye erişme ve kullanma sürecinde yapılan davranış ve yaşanan olaylardır.

Bütün kütüphanelerin var oluş nedeni ve amacı kendi kullanıcılarının bilgi gereksinimini uygun bir şekilde karşılamaktır (Uçak, 1999, s.116). Yeni teknolojik gelişmelere bağlı olarak üniversite kütüphaneleri hizmetlerinde meydana gelen değişiklikler, kullanıcı davranışlarını da olumlu veya olumsuz şekilde etkilemiştir (Kaygusuz, 2004, s.21).

Bilgi ve iletişim teknolojilerinin 1970'li yıllardan itibaren kütüphanelere getirdiği ilk ve en önemli değişiklik, kart katalogların bilgisayar ortamına aktarılmasıdır. Bu durum, aradan geçen süre içinde çarpıcı bir şekilde gelişmiş; bugün artık hemen her üniversite kütüphanesi, sahip olduğu verita banlarını ve dijital bilgi kaynaklarını internet üzerinden 24 saat erişime sunar hale gelmiştir. Yüzyıllarca geleneksel kütüphanelerdeki bilgi kaynaklarına birkaç farklı kart katalogdan faydalanarak zorlukla erişebilen kullanıcılar, günümüzde kısa bir sürede evlerinden veya işyerlerinden çeşitli kütüphanelerin bilgi kaynaklarına erişebilme olanağına sahip olmuştur. Daha önce yazar, eser adı ve konu katalogları aracılığıyla kütüphanelerin kaynaklarına erişebilen kullanıcılar, yeni bilgi ve iletişim teknolojileri sayesinde daha çok erişim noktasından aramalar yapabilmekte ve aradığı kaynaklara daha kısa bir süre içinde ulaşmaktadır. Bu durumun kullanıcılar için en önemli yararı, dünyada yapılan çalışmalara rahatlıkla erişebilmeleri ve değerlendirebilmeleridir. Bu bağlamda kütüphanelerin internet üzerinden bilgi hizmeti vermesi aşağıdaki avantajları beraberinde getirmiştir:

$\diamond$ Araştırmacılar literatür taramalarında onlarca cilt yayını tek tek aramak yerine, çevrimiçi veri tabanları aracılığıyla kısa bir sürede bu işlemi yapabilmektedirler. 
Geçmişte sadece kütüphanelerin çalışma saatleri içerisinde yapılabilen literatür taramaları, günümüzde zaman ve mekan sınırı olmadan internet üzerinden gerçekleştirilebilmektedir.

$\diamond$ Kullanııılar, kütüphanelerin abone olduğu e-dergi, e-kitap ve diğer dijital bilgi kaynaklarından yararlanmak için günün herhangi bir saatinde bu dergilerin elektronik kopyalarından kütüphanelerin web siteleri aracılığılla yararlanabilmektedir.

Geleneksel bilgi kaynaklarıyla karşılaştııldığında dijital bilgi kaynakları ayrıca, etkileşim, bilgiye hızlı ve kısa sürede erişim, çoklu ortam (metin, ses, resim, görsel ve işitsel) imkânları sunması bakımından önemli faydalar sağlamaktadır.

Günümüzde kullanıcılar ise, bilgi kaynaklarının basılı kopyalarının kütüphaneye gelmesini beklememekte, elektronik kopyalarından yararlanarak bir an önce bu kaynaklara ulaşmayı tercih etmektedirler. Bunun yanı sıra kütüphaneler, giderek basılı aboneliklerini iptal ederek elektronik aboneliklere geçmektedirler.

Bilgi ve iletişim teknolojilerin etkisiyle kütüphanelerin hizmetlerinde yaşanan gelişimler, sosyolojik, ekonomik, kültürel ve psikolojik değişmelere de neden olmuştur. Kütüphane kullanıııları yıllarca sürdürdükleri alışkanlıklarını ve davranışlarını kısa bir süre içinde terk ederek yeni davranış biçimleri geliştirmek zorunda kalmışlardır. Günümüzün gereği olan bu gelişmeleri ve değişmeleri genç nesiller daha kolay biçimde benimserken; daha eski olanlar alışkanlıklarını ve davranışlarını kolay biçimde değiştirememişlerdir (Kaygusuz, 2004, s. 21).

Dijital bilgi kaynaklarının ortaya çıkışı ve bilginin dijital ortamda üretimi, depolaması, düzenlenmesi ve internet üzerinden erişime sunulması, bilim adamlarının davranışlarını derinden etkilemiştir. Dijital ortamın bilgi okuma ve arama davranışına etkisi, psikoloji, bilgisayar bilimi, eğitim bilimleri, okuryazarlık araştırmaları ve bilgi yönetimi gibi bilim dallarının araştırma konuları olmuştur. Dijital ortamda bilginin artışı ve kullanıcıların bu bilgileri okumak için ayırdığı zaman ve bu ortamın bireylerin bilgi arama davranışlarına etkisi, bilgi arama davranışları araştırmalarını gündeme getirmiştir. Bazı bilim adamlarına göre ise dijital ortamın bulunuşu, bunun yanı sıra çeşitli dijital metinlerin dağınık biçimde olması, kullanıcıların sürekli okuma alışkanlığını tehdit etmektedir. Birkertz'e göre, dijital ortamda gelişen yeni genç nesiller, bilimsel konuları uzun süreli ve eleştirel olarak okumakta güçlük çekmektedirler (Healy, 1990; Birkerts, 1994).

Basılı ortamdan dijital ortama geçiş, okuryazarlığın sona ermesi anlamına gelmemektedir. Yeni teknolojiler, yeni bir bilgi okuryazarlık, üretme ve kullanma ortamını kullanıcılara ve özellikle de bilim adamlarına sunmakta; kullanıııların bilgi arama davranışlarının değişmesi sürecinde önemli rol oynamaktadır (Liu, 2005, s.701). 


\section{Yöntem}

Bu çalışmanın odak grubunu İran Tebriz'deki üniversitelerde görev yapan öğretim üyeleri oluşturmaktadır. Çalışma kapsamında Tebriz, Azerbaycan Terbiyet-i Moellem, Tebriz Sağlık Bilimleri, İslami Azat ve Endüstri Sehend üniversitelerinde görevli toplam 354 öğretim üyesinin bilgi arama davranışları incelenmiştir.

Çalışma evreni, beş üniversitede çalışan toplam 1907 öğretim üyesinden oluşmaktadır. Her üniversitenin öğretim üyelerinin çalışmada yer alabilmesini sağlamak amacıyla, üniversiteler arasında seçim yapılmadan tamamı araştırmaya dâhil edilmiş; rastgele örnekleme yönteminden yararlanarak belirlenen 408 öğretim üyesine 29 sorudan oluşan anket uygulanmıştır. 54 anket formu öğretim üyelerinin cevaplarının anlamsız olması nedeniyle çalışma kapsamından çıkarılmıştır.

354 anketin verileri ışığında, Tebriz'deki üniversitelerin sağlık, fen ve sosyal bilim dallarında çalışan öğretim üyelerinin bilgi gereksinimleri, bilgi arama davranışları, bilgi ve iletişim teknolojilerinin öğretim üyeleri üzerindeki etkisi ve bu süreçte meydana çıkan özellikler saptanmıştır.

\section{Bulgular ve Değerlendirme}

Araştırma kapsamında bulunan Tebriz'deki üniversitelerde görev yapan öğretim üyelerinin yaşları ve cinsiyetlerine ilişkin bilgiler Tablo l'de; akademik unvanları ise Tablo II'de sunulmuştur.

Tablo l'deki bulgulara göre araştırmaya katılan öğretim üyelerinin çoğunluğu sağlık ve fen bilimcilerinden oluşmaktadır. Yaş dağılımlarına bakıldığında ise büyük çoğunluğun 25-50 yaş aralığında olduğu görülmektedir. 61-65 yaş aralığında sağlık ve fen bilimcilerinden kimse yer almamaktadırlar. Araştırmaya katılan kişilerin \%76.8'ini (272) erkekler, \%23.2'sini (82) ise kadınlar oluşturmaktadır. 
Tablo I. Öğretim Üyelerinin Yaşları ve Cinsiyetleri

\begin{tabular}{|c|c|c|c|c|c|c|}
\hline \multirow{2}{*}{ Yaş } & \multicolumn{2}{|c|}{ Sağlık } & \multicolumn{2}{|c|}{ Fen } & \multicolumn{2}{|c|}{ Sosyal } \\
\hline & $\begin{array}{c}\text { Erkek } \\
\text { (Sayı) \% }\end{array}$ & $\begin{array}{l}\text { Kadın } \\
\text { (Sayı) \% }\end{array}$ & $\begin{array}{c}\text { Erkek } \\
\text { (Sayı) \% }\end{array}$ & $\begin{array}{c}\text { Kadın } \\
\text { (Sayı) \% }\end{array}$ & $\begin{array}{c}\text { Erkek } \\
\text { (Sayı) \% }\end{array}$ & $\begin{array}{c}\text { Kadın } \\
\text { (Sayı) \% }\end{array}$ \\
\hline \multirow{2}{*}{$25-30$} & (18) & (8) & (10) & (7) & (9) & (4) \\
\hline & 12.9 & 5.7 & 7.4 & 5.1 & 11.5 & 5.0 \\
\hline \multirow{2}{*}{$31-35$} & (22) & (12) & (30) & (6) & (13) & (7) \\
\hline & 15.7 & 8.6 & 22.1 & 4.4 & 16.7 & 9.0 \\
\hline \multirow{2}{*}{$36-40$} & (21) & (17) & (32) & (2) & (9) & (2) \\
\hline & 15.0 & 12.1 & 23.5 & 1.5 & 11.5 & 2.6 \\
\hline \multirow{2}{*}{$41-45$} & (12) & (11) & (23) & (0) & (18) & 0 \\
\hline & 8.6 & 7.9 & 16.9 & 0.0 & 23.2 & 0.0 \\
\hline \multirow{2}{*}{$46-50$} & (9) & (5) & (14) & (0) & (8) & 0 \\
\hline & 6.4 & 3.6 & 10.3 & 0.0 & 10.3 & 0.0 \\
\hline \multirow{2}{*}{$51-55$} & (3) & (0) & (9) & (0) & (3) & (1) \\
\hline & 2.1 & 0.0 & 6.6 & 0.0 & 3.8 & 1.3 \\
\hline \multirow{2}{*}{$56-60$} & (2) & (0) & (3) & (0) & (3) & 0 \\
\hline & 1.4 & 0.0 & 2.2 & 0.0 & 3.8 & 0.0 \\
\hline \multirow{2}{*}{$61-65$} & $(0)$ & (0) & (0) & (0) & (1) & 0 \\
\hline & 0.0 & 0.0 & 0.0 & 0.0 & 1.3 & 0.0 \\
\hline \multirow{2}{*}{ Toplam } & (87) & (53) & (121) & (15) & (64) & (14) \\
\hline & 62.1 & 37.9 & 89.0 & 11.0 & 82.1 & 17.9 \\
\hline \multirow{2}{*}{ Toplam (Erkek ve Kadın) } & \multicolumn{2}{|c|}{$(140)$} & \multicolumn{2}{|c|}{ (136) } & \multicolumn{2}{|c|}{ (78) } \\
\hline & \multicolumn{2}{|c|}{100} & \multicolumn{2}{|c|}{100} & \multicolumn{2}{|c|}{100} \\
\hline
\end{tabular}


Tablo II. Öğretim Üyelerinin Akademik Unvanları

\begin{tabular}{|c|c|c|c|c|c|c|}
\hline \multirow[b]{2}{*}{ Akademik Unvanlar } & \multicolumn{2}{|c|}{ Sağlık } & \multicolumn{2}{|c|}{ Fen } & \multicolumn{2}{|c|}{ Sosyal } \\
\hline & $\begin{array}{c}\text { Erkek } \\
\text { (Sayı) \% }\end{array}$ & $\begin{array}{c}\text { Kadın } \\
\text { (Sayı) \% }\end{array}$ & $\begin{array}{c}\text { Erkek } \\
\text { (Sayı) \% }\end{array}$ & $\begin{array}{c}\text { Kadın } \\
\text { (Sayı) \% }\end{array}$ & $\begin{array}{c}\text { Erkek } \\
\text { (Sayı) \% }\end{array}$ & $\begin{array}{c}\text { Kadın } \\
\text { (Sayı) \% }\end{array}$ \\
\hline \multirow{2}{*}{ Profesör Doktor } & (5) & (0) & (4) & (0) & (0) & (0) \\
\hline & 3.7 & 0.0 & 2.9 & 0.0 & 0.0 & 0.0 \\
\hline \multirow{2}{*}{ Doçent Doktor } & $(21)$ & $(0)$ & (10) & (6) & $(12)$ & (0) \\
\hline & 15.4 & 0.0 & 7.1 & 4.3 & 15.4 & 0.0 \\
\hline \multirow{2}{*}{ Yardım Doçent Doktor } & (71) & (5) & (48) & (12) & (26) & (5) \\
\hline & 52.2 & 3.7 & 34.3 & 8.6 & 33.3 & 6.4 \\
\hline \multirow{2}{*}{ Öğretim Görevlisi } & (18) & (9) & (19) & $(28)$ & (24) & (7) \\
\hline & 13.2 & 6.6 & 13.6 & 20.0 & 30.8 & 8.9 \\
\hline \multirow{2}{*}{ Doktora Öğrencisi } & (5) & (0) & (4) & (8) & (0) & (1) \\
\hline & 3.7 & 0.0 & 2.8 & 5.7 & 0.0 & 1.3 \\
\hline \multirow{2}{*}{ Okutman } & (2) & (0) & (1) & (0) & (2) & (1) \\
\hline & 1.5 & 0.0 & 0.7 & 0.0 & 2.6 & 1.3 \\
\hline \multirow{2}{*}{ Toplam } & (122) & (14) & (86) & 54) & (64) & (14) \\
\hline & 89.7 & 10.3 & 61.4 & 38.6 & 82.1 & 17.9 \\
\hline \multirow{2}{*}{ Toplam: Erkek ve Kadın } & \multicolumn{2}{|c|}{ (140) } & \multicolumn{2}{|c|}{ (136) } & \multicolumn{2}{|c|}{ (78) } \\
\hline & \multicolumn{2}{|c|}{100} & \multicolumn{2}{|c|}{100} & \multicolumn{2}{|c|}{100} \\
\hline
\end{tabular}

Tablo II verilerine göre sağlık, fen ve sosyal Bilimler dalında çalışan öğretim üyelerinin büyük çoğunluğu yardımcı doçentlerden, en az oranı ise okutmanlardan oluşmaktadır. Araştırmaya katılanlar arasında sosyal bilimler alanından profesör doktor bulunmamaktadır.

\section{Öğretim Üyelerinin Bilgi Gereksinimleri}

Sağlık, fen ve sosyal bilimler dalında çalışan öğretim üyelerinin bilgiye duydukları gereksinimleri ortaya koyan veriler Tablo III'te sunulmuştur.

Tablo Ill'e göre, sağlık, fen ve sosyal Bilimler dallarında çalışan öğretim üyeleri en çok araştırmalarıyla ilgili bilgi gereksinimi duymaktadırlar. Araştırmalarıyla ilgili bilgi gereksinimi duyan öğretim üyelerinin büyük çoğunluğu (\%96.4) sağlık bilimleri alanında çalışmaktadır. Fen ve sağlık alanındaki öğretim üyeleri ikinci sırada derse hazırlık kapsamında bilgi gereksinimi duymaktadır. Sosyal bilimler alanında ise ikinci 
Tablo III. Öğretim Üyelerinin Bilgiye Gereksinimleri

\begin{tabular}{|c|c|c|c|c|c|c|c|c|}
\hline $\begin{array}{l}\text { Bilim } \\
\text { Dalları }\end{array}$ & $\begin{array}{c}\text { Derse } \\
\text { Hazırlık }\end{array}$ & $\begin{array}{c}\text { Tez } \\
\text { Çalışması }\end{array}$ & Araştırma & $\begin{array}{c}\text { Makale/ } \\
\text { Kitap/Bildiri }\end{array}$ & Proje & Danışmanlık & $\begin{array}{l}\text { Bilimsel } \\
\text { Gelişmeler }\end{array}$ & Toplam \\
\hline & (Sayı) & (Sayı) & (Sayı) & (Sayı) & (Sayı) & (Sayı) & (Sayı) & (Sayı) \\
\hline & $\%$ & $\%$ & $\%$ & $\%$ & $\%$ & $\%$ & $\%$ & $\%$ \\
\hline \multirow{2}{*}{ Sağlık } & (115) & (98) & (135) & (83) & $(82)$ & (52) & (99) & $(140)$ \\
\hline & 82.1 & 70.0 & 96.4 & 59.3 & 58.6 & 37.1 & 70.7 & 100 \\
\hline \multirow{2}{*}{ Fen } & (115) & (83) & (124) & (79) & (59) & (41) & (70) & (136) \\
\hline & 84.6 & 61.0 & 91.2 & 58.1 & 43.4 & 30.1 & 51.5 & 100 \\
\hline \multirow{2}{*}{ Sosyal } & (64) & $(40)$ & (73) & (65) & (30) & (23) & (45) & (78) \\
\hline & 82.1 & 51.3 & 93.6 & 83.3 & 38.5 & 29.5 & 57.7 & 100 \\
\hline
\end{tabular}

sırada makale/kitap/bildiri hazırlamak yer almaktadır. Danışmanlık amacıyla bilgiye duyulan gereksinim tüm alanlarda en az orandadır.

\section{Elektronik Bilgi Kaynaklarının Kullanımı}

Sağlık, fen ve sosyal bilimler dallarında çalışan öğretim üyelerinin elektronik bilgi kaynaklarını kullanmalarına yönelik veriler Tablo IV'tedir.

Tablo IV'deki bulgulara bakıldığında, sağlık, fen ve sosyal bilimler alanlarında elektronik dergi, en çok kullanılan elektronik bilgi kaynağı olarak görülmektedir. Tüm alanlarda elektronik dergi kullanımını sırasıyla elektronik kitap ve elektronik tez kullanımı takip etmektedir. Elektronik dergileri en fazla sağlık bilimleri alanında çalışanlar kullanmaktadır. Tüm alanlar için en az tercih edilen elektronik bilgi kaynağı türü ise elektronik standartlardır.

Tablo IV. Öğretim Üyelerinin Elektronik Bilgi Kaynaklarını Kullanımı

\begin{tabular}{|c|c|c|c|c|c|c|c|c|c|c|}
\hline $\begin{array}{l}\text { Bilim } \\
\text { Dalları }\end{array}$ & E-Kitap & E-Dergi & E-Tez & $\begin{array}{c}\text { E-Öz, } \\
\text { E-Dizin }\end{array}$ & $\begin{array}{c}\text { E-Toplantı } \\
\text { Metni }\end{array}$ & E-Patent & E-Rapor & E-Standard & E-Gazete & Toplam \\
\hline & (Sayı) & (Sayı) & (Sayı) & (Sayı) & (Sayı) & (Sayı) & (Sayı) & (Sayı) & (Sayı) & (Sayı) \\
\hline & $\%$ & $\%$ & $\%$ & $\%$ & $\%$ & $\%$ & $\%$ & $\%$ & $\%$ & $\%$ \\
\hline \multirow{2}{*}{ Sağlık } & (112) & (138) & (88) & (74) & (76) & (28) & (35) & (25) & (44) & (140) \\
\hline & 80.0 & 98.6 & 62.9 & 52.9 & 54.3 & 20.0 & 25.0 & 17.9 & 31.4 & 100 \\
\hline \multirow{2}{*}{ Fen } & (121) & (129) & (99) & (66) & (69) & (32) & (34) & (30) & (64) & (136) \\
\hline & 89.0 & 94.9 & 72.8 & 48.5 & 50.7 & 23.5 & 25.0 & 22.1 & 47.1 & 100 \\
\hline \multirow{2}{*}{ Sosyal } & (64) & (70) & (46) & (41) & (42) & (12) & (19) & (11) & (38) & (78) \\
\hline & 82.1 & 89.7 & 59.0 & 52.6 & 53.8 & 15.4 & 24.4 & 14.1 & 48.7 & 100 \\
\hline
\end{tabular}


Tablo V. Öğretim Üyelerinin Basılı Bilgi Kaynakları Kullanımı

\begin{tabular}{lcccccccccc}
\hline $\begin{array}{l}\text { Bilim } \\
\text { Dalları }\end{array}$ & Kitap & Dergi & Tez & $\begin{array}{c}\text { Öz, } \\
\text { Dizin }\end{array}$ & $\begin{array}{c}\text { Toplantı } \\
\text { Metni }\end{array}$ & Patent & Rapor & Standard & Gazete & Toplam \\
\hline \multirow{6}{*}{ Sağlık } & $($ Sayı) & $($ Sayı) & $($ Sayı) & $($ Sayı) & $($ Sayı) & $($ Sayı) & $($ Sayı) & $($ Sayı) & $($ Sayı) & $($ Sayı) \\
& $\%$ & $\%$ & $\%$ & $\%$ & $\%$ & $\%$ & $\%$ & $\%$ & $\%$ & $\%$ \\
& $(138)$ & $(132)$ & $(94)$ & $(69)$ & $(71)$ & $(28)$ & $(44)$ & $(31)$ & $(51)$ & $(140)$ \\
\multirow{2}{*}{ Fen } & 98.6 & 94.3 & 67.1 & 49.3 & 50.7 & 20.0 & 31.4 & 22.1 & 36.4 & 100 \\
& $(136)$ & $(126)$ & $(102)$ & $(52)$ & $(60)$ & $(28)$ & $(34)$ & $(40)$ & $(49)$ & $(136)$ \\
\multirow{2}{*}{ Sosyal } & 100 & 92.6 & 75.0 & 38.2 & 44.1 & 20.6 & 25.0 & 29.4 & 36.0 & 100 \\
& $(77)$ & $(73)$ & $(55)$ & $(46)$ & $(40)$ & $(9)$ & $(11)$ & $(7)$ & $(30)$ & $(78)$ \\
& 98.7 & 93.6 & 70.5 & 59.0 & 51.3 & 11.5 & 14.1 & 9.0 & 38.5 & 100 \\
\hline
\end{tabular}

\section{Basılı Bilgi Kaynaklarının Kullanımı}

Öğretim üyelerinin basılı ortamdaki bilgi kaynakları kullanımlarını yansıtan veriler Tablo V'de verilmiştir.

Sağlık, fen ve sosyal bilimler alanında öğretim üyelerinin en fazla tercih ettiği basılı bilgi kaynağı kitaptır. Gruplar arasında kitap, \%100 oranıyla en çok fen bilimleri alanında çalışan öğretim üyeleri tarafından kullanılmaktadır. Sosyal (\%98.7) ve sağlık (\%98.6) bilimleri alanında basılı kitap kullanım oranı ise \%100'e oldukça yakındır. Tüm bilim alanlarında kitap kullanımını sırasıyla en çok basılı dergi ve basılı tezler takip etmektedir. Tüm alanlarda en az tercih edilen basılı bilgi kaynağı ise patentlerdir.

\section{Danışma Kaynaklarının Kullanımı}

Sağlık, fen ve sosyal bilimler dallarında çalışan öğretim üyelerinin danışma kaynaklarını kullanmalarına ilişkin veriler Tablo VI'dadır.

Tablo Vı incelendiğinde, danışma kaynaklarının kullanımında alanlar arasında bazı farklılıkların olduğu görülmektedir. Sağlık ve fen bilimleri alanında çalışanlar danışma kaynağı olarak en fazla el kitaplarını kullanmayı tercih ederken, sosyal bilimler alanında çalışanlar en fazla ansiklopedileri tercih etmektedir. Sağlık ve fen bilimleri alanında çalışanların ikinci sıradaki tercihleri ansiklopediler iken, sosyal bilimler alanında çalışanların ise sözlüklerdir. Danışma kaynaklarının kullanımı ile ilgili olarak sağlık ve fen bilimleri alanlarında çalışan öğretim üyelerinin tercihlerinin birbirine paralel olduğu, sosyal bilimler alanındaki öğretim üyelerinin tercihlerinin diğer alanlardakilerden farklılık gösterdiği söylenebilir. İstatistikler ve standartlar ise tüm alanlarda genel olarak kullanılmamaktadır. 
Tablo Vı. Öğretim Üyelerinin Danışma Kaynakları Kullanımı

\begin{tabular}{|c|c|c|c|c|c|c|c|c|c|c|c|c|c|}
\hline $\begin{array}{l}\text { Bilim } \\
\text { Dalları }\end{array}$ & $\begin{array}{l}\text { Ansik- } \\
\text { lopedi }\end{array}$ & Sözlük & $\begin{array}{c}\text { Öz I } \\
\text { Dizin }\end{array}$ & $\begin{array}{c}\text { Bibli- } \\
\text { yograf- } \\
\text { ya }\end{array}$ & $\begin{array}{l}\text { Biyo- } \\
\text { grafi }\end{array}$ & $\begin{array}{c}\text { El Ki- } \\
\text { tabı }\end{array}$ & Yıllık & $\begin{array}{l}\text { Reh- } \\
\text { ber }\end{array}$ & $\begin{array}{c}\text { Harita } \\
\text { ve } \\
\text { Atlas }\end{array}$ & $\begin{array}{l}\text { İsta- } \\
\text { tistik }\end{array}$ & $\begin{array}{c}\text { Stan- } \\
\text { dart }\end{array}$ & $\begin{array}{c}\text { Kullan- } \\
\text { mıyo- } \\
\text { rum }\end{array}$ & $\begin{array}{l}\text { Top- } \\
\text { lam }\end{array}$ \\
\hline & (Sayı) & (Sayı) & (Sayı) & (Sayı) & (Sayı) & (Sayı) & (Sayı) & (Sayı) & (Sayı) & (Sayı) & (Sayı) & (Sayı) & (Sayı) \\
\hline & $\%$ & $\%$ & $\%$ & $\%$ & $\%$ & $\%$ & $\%$ & $\%$ & $\%$ & $\%$ & $\%$ & $\%$ & $\%$ \\
\hline \multirow{2}{*}{ Sağlık } & (98) & (66) & (71) & (31) & (27) & (123) & (23) & (33) & (96) & (0) & (0) & (0) & (140) \\
\hline & 70.0 & 47.1 & 50.7 & 22.1 & 19.3 & 87.9 & 16.4 & 23.6 & 68.6 & 0.0 & 0.0 & 0.0 & 100 \\
\hline \multirow{2}{*}{ Fen } & (92) & (68) & (65) & (24) & (12) & (104) & (29) & (30) & (32) & (1) & (1) & (1) & (136) \\
\hline & 67.6 & 50.0 & 47.8 & 17.6 & 8.8 & 76.5 & 21.3 & 22.1 & 23.5 & 0.7 & 0.7 & 0.7 & 100 \\
\hline \multirow{2}{*}{ Sosyal } & (67) & (57) & (43) & (31) & (26) & (40) & (22) & (17) & (15) & (0) & (0) & (0) & (78) \\
\hline & 85.9 & 73.1 & 55.1 & 39.7 & 33.3 & 51.3 & 28.2 & 21.8 & 19.2 & 0.0 & 0.0 & 0.0 & 100 \\
\hline
\end{tabular}

\section{Bilgi Arama Davranışları}

Öğretim üyelerinin çalışma alanları ile ilgili bilgi arama davranışlarına yönelik veriler Tablo VII'de sunulmuştur.

Tablo VII verileri ışığında, tüm bilim alanlarındaki öğretim üyelerinin tamamına yakını bilgi aramada öncelikle kütüphanelerdeki bilgi kaynaklarına başvurmaktadırlar. Sağlık ve fen bilimleri alanında çalışanlar bilgi aramada en çok elektronik ortamdaki kaynaklardan yararlanmayı; sosyal bilimler alanında çalışanlar ise en çok merkezi ve fakülte kütüphanelerini kullanmayı tercih etmektedirler. Tüm bilim alanları için bilgi aramada öğretim üyelerinin tercih ettiği ikinci davranış ise kendi kişisel bilgi kaynaklarını kullanmaktır. Sağlık bilimleri alanında çalışan öğretim üyelerinin bilgi aramada diğer meslektaşlarına danışması (\%60.7) azımsanmayacak orandadır.

Tablo VII. Öğretim Üyelerinin Bilgi Arama Davranışları

\begin{tabular}{|c|c|c|c|c|c|c|c|c|}
\hline $\begin{array}{l}\text { Bilim } \\
\text { Dalları }\end{array}$ & $\begin{array}{c}\text { Kişisel } \\
\text { Kaynakla- } \\
\text { rın Kullanı- } \\
\text { mı }\end{array}$ & $\begin{array}{c}\text { Bölüm- } \\
\text { deki } \\
\text { Kitaplığın } \\
\text { Kullanımı }\end{array}$ & $\begin{array}{l}\text { Bölümdeki } \\
\text { Meslek- } \\
\text { taşlarla Danı- } \\
\text { şılması }\end{array}$ & $\begin{array}{l}\text { Bölüm Dı- } \\
\text { şındaki Mes- } \\
\text { lektaşlara } \\
\text { Danışıması }\end{array}$ & $\begin{array}{l}\text { Konuyla ilgili } \\
\text { Yayımlanan } \\
\text { Bilimsel } \\
\text { Toplantıların } \\
\text { Kullanımı }\end{array}$ & $\begin{array}{c}\text { Merkezi } \\
\text { ve Fakülte } \\
\text { Kütüphane- } \\
\text { lerin } \\
\text { Kullanımı }\end{array}$ & $\begin{array}{c}\text { Elektronik } \\
\text { Ortamdaki } \\
\text { Kaynaklar- } \\
\text { dan Yarar- } \\
\text { lanma }\end{array}$ & $\begin{array}{l}\text { Top- } \\
\text { lam }\end{array}$ \\
\hline & (Sayı) & (Sayı) & (Sayı) & (Sayı) & (Sayı) & (Sayı) & (Sayı) & (Sayı) \\
\hline & $\%$ & $\%$ & $\%$ & $\%$ & $\%$ & $\%$ & $\%$ & $\%$ \\
\hline \multirow{2}{*}{ Sağlık } & (96) & (60) & (85) & (55) & (67) & (119) & (132) & (140) \\
\hline & 68.6 & 42.9 & 60.7 & 39.3 & 47.9 & 85.0 & 94.3 & 100 \\
\hline \multirow{2}{*}{ Fen } & (100) & (34) & (63) & (42) & (63) & (119) & (133) & (136) \\
\hline & 73.5 & 25.0 & 46.3 & 30.9 & 46.3 & 87.5 & 97.8 & 100 \\
\hline \multirow{2}{*}{ Sosyal } & (66) & (37) & (35) & (24) & (33) & (74) & (66) & (78) \\
\hline & 84.6 & 47.4 & 44.9 & 30.9 & 42.3 & 94.9 & 84.6 & 100 \\
\hline
\end{tabular}


Tablo VıII. Öğretim Üyelerinin Kullandıkları Bilgi Kayıt Ortamları

\begin{tabular}{lcccc}
\hline Bilim Dalları & $\begin{array}{c}\text { Meslektaşlarına } \\
\text { Danışma }\end{array}$ & $\begin{array}{c}\text { Basılı Kaynaklara } \\
\text { Başvurma }\end{array}$ & $\begin{array}{c}\text { Elektronik Kaynaklara } \\
\text { Başvurma }\end{array}$ & Toplam \\
\cline { 2 - 5 } & $\begin{array}{c}\text { (Sayı) } \\
\%\end{array}$ & $\begin{array}{c}\text { (Sayı) } \\
\%\end{array}$ & $\begin{array}{c}\text { (Sayı) } \\
\%\end{array}$ & $\begin{array}{c}\text { (Sayı) } \\
\%\end{array}$ \\
\hline \multirow{2}{*}{ Sağlık } & $(105)$ & $(115)$ & $(119)$ & $(140)$ \\
& 75.0 & 82.1 & 85.0 & 100 \\
Fen & $(104)$ & $(120)$ & $(133)$ & $(136)$ \\
& 76.5 & 88.2 & 97.8 & 100 \\
Sosyal & $(63)$ & $(76)$ & $(72)$ & $(78)$ \\
& 80.8 & 97.4 & 92.3 & 100 \\
\hline
\end{tabular}

\section{Bilgi Kayıt Ortamları}

Öğretim üyelerinin bilgi gereksinimlerini karşılamada kullandıkları bilgi kayıt ortamlarına ilişkin bilgiler Tablo VIII'de yer almaktadır.

Tablo VIII'e göre, sağlık ve fen bilimleri alanında çalışan öğretim üyelerinin en fazla elektronik ortamda kayıtlı bilgi kaynaklarına; sosyal bilimler alanında çalışan öğretim üyelerinin ise daha çok basılı ortamda kayıtlı bilgi kaynaklarına başvurdukları görülmektedir. Meslektaşlarına danışma ise en çok sosyal bilimler alanında çalışan öğretim üyelerince gerçekleştirilmektedir.

\section{Bilgi Aramada Tercihler}

Öğretim üyelerinin bilgi arama işlemlerindeki tercihlerine yönelik veriler Tablo IX'da sunulmuştur.

Tablo IX. Öğretim Üyelerinin Bilgi Aramadaki Tercihleri

\begin{tabular}{|c|c|c|c|c|c|c|c|c|c|c|c|}
\hline \multirow[t]{3}{*}{$\begin{array}{l}\text { Bilim } \\
\text { Dalları }\end{array}$} & Orijinal & Güncel & Doğruluk & Güvenirlik & $\begin{array}{c}\text { Erişim } \\
\text { Kolay- } \\
\text { lığı }\end{array}$ & Dili & Format & Kapsam & $\begin{array}{c}\text { Yazar } \\
\text { Ve } \\
\text { Yayıncı }\end{array}$ & $\begin{array}{l}\text { Önce Kul- } \\
\text { lanılan }\end{array}$ & Toplam \\
\hline & (Sayı) & (Sayı) & (Sayı) & (Sayı) & (Sayı) & (Sayı) & (Sayı) & (Sayı) & (Sayı) & (Sayı) & (Sayı) \\
\hline & $\%$ & $\%$ & $\%$ & $\%$ & $\%$ & $\%$ & $\%$ & $\%$ & $\%$ & $\%$ & $\%$ \\
\hline \multirow{2}{*}{ Sağlık } & (118) & (139) & (124) & (107) & (95) & $(102)$ & (68) & (79) & (75) & (63) & (140) \\
\hline & 84.3 & 99.3 & 88.6 & 76.4 & 67.9 & 72.9 & 48.6 & 56.4 & 53.6 & 45.0 & 100 \\
\hline \multirow{2}{*}{ Fen } & (107) & (123) & (107) & (73) & (87) & (81) & (51) & (45) & (77) & (53) & (136) \\
\hline & 78.7 & 90.4 & 78.7 & 53.7 & 64.0 & 59.6 & 37.5 & 33.1 & 56.6 & 39.0 & 100 \\
\hline \multirow{2}{*}{ Sosyal } & (63) & (65) & (67) & (48) & (46) & (47) & (32) & (29) & (43) & (31) & (78) \\
\hline & 80.8 & 83.3 & 85.9 & 61.5 & 59.0 & 60.3 & 41 & 37.2 & 55.1 & 39.7 & 100 \\
\hline
\end{tabular}


Tablo IX'a göre sağlık bilimleri alanında çalışanlar bilgi aramada sırasıyla en fazla güncelliğe (\%99.3), doğruluğa (\%88.6) ve orijinalliğe (84.3) önem vermektedir. Fen bilimleri alanında çalışanların tercihleri güncellik (90.4), orijinallik (78.7) ve doğruluk (78.7) sırasıyladır. Sosyal bilimler alanında çalışanlar ise önce doğruluğa (85.9), sonra güncellik (83.3) ve orijinalliğe (80.8) dikkat etmektedirler.

\section{Yayın Taramaları}

Öğretim üyelerinin yayın taramaları yaparken tercihlerini yansıtan veriler Tablo X'da gösterilmektedir.

Tablo X. Öğretim Üyelerinin Yayın Taramalarındaki Tercihleri

\begin{tabular}{lcccc}
\hline Bilim Dalları & $\begin{array}{c}\text { Taramayı Kendim } \\
\text { Yaparım } \\
\text { (Sayı) } \\
\%\end{array}$ & $\begin{array}{c}\text { Kütüphaneciden } \\
\text { Yardım İsterim } \\
\text { (Sayı) } \\
\%\end{array}$ & $\begin{array}{c}\text { Uzman Birisinden } \\
\text { Yardım İsterim }\end{array}$ & $\begin{array}{c}\text { Toplam } \\
\text { (Sayı) } \\
\%\end{array}$ \\
\hline Sağlık & $(140)$ & $(95)$ & $(59)$ & (Sayı) \\
& 100 & 67.9 & 42.1 & $(140)$ \\
Fen & $(136)$ & $(82)$ & $(65)$ & 100 \\
& 100 & 60.3 & 47.8 & $(136)$ \\
Sosyal & $(76)$ & $(43)$ & $(30)$ & 100 \\
\hline
\end{tabular}

Sağlık, fen ve sosyal bilimler alanlarında çalışan öğretim üyelerinin yayın tarama davranışları ile ilgili Tablo $X$ verileri incelendiğinde, her üç bilim alanında da öğretim üyelerinin çoğunlukla yayın tarama işlemlerini kendilerinin yaptığı görülmektedir. Kütüphaneciden yardım almayı en çok (67.9) sağlık bilimleri alanında çalışan öğretim üyeleri tercih etmektedirler.

Öğretim üyelerinin yayın taramalarını gerçekleştirirken ortaya koyduğu davranışlara ilişkin veriler Tablo XI'de sunulmuştur.

Tablo Xl'e göre sağlık ve fen bilimleri alanlarında görev yapan öğretim üyeleri yayın taraması yaparken en çok veri tabanlarından yararlanma, sosyal bilimler alanındakiler ise makalelerin kaynakçalarını araştırma davranışlarını göstermektedirler. Yayın taramaları işlemlerinde tüm bilim alanları için en az kütüphane katalogları tercih edilmektedir. 
Tablo XI. Öğretim Üyelerinin Yayın Taramalarındaki Davranışları

\begin{tabular}{lcccccc}
\hline $\begin{array}{l}\text { Bilim } \\
\text { Dalları }\end{array}$ & $\begin{array}{c}\text { Kitapların } \\
\text { Kaynakçaları- } \\
\text { nı Araştırma }\end{array}$ & $\begin{array}{c}\text { Makalelerin } \\
\text { Kaynakçalarını } \\
\text { Araştırma }\end{array}$ & $\begin{array}{c}\text { Indeksleri, Özleri } \\
\text { ve Bibliyografya- } \\
\text { ları Tarama }\end{array}$ & $\begin{array}{c}\text { Veri Ta- } \\
\text { banlarını } \\
\text { Tarama }\end{array}$ & $\begin{array}{c}\text { Kütüphane } \\
\text { Kataloglarını } \\
\text { Tarama }\end{array}$ & Toplam \\
\hline \multirow{2}{*}{ (Sayı) } & $\begin{array}{c}\text { (Sayı) } \\
\text { \% }\end{array}$ & $\begin{array}{c}\text { (Sayı) } \\
\%\end{array}$ & $\begin{array}{c}\text { (Sayı) } \\
\%\end{array}$ & $\begin{array}{c}\text { (Sayı) } \\
\%\end{array}$ & $\begin{array}{c}\text { (Sayı) } \\
\%\end{array}$ \\
\hline \multirow{2}{*}{ Sağlık } & $(77)$ & $(127)$ & $(89)$ & $(135)$ & $(63)$ & $(140)$ \\
& 55.0 & 90.7 & 63.6 & 96.4 & 45.0 & 100 \\
Fen & $(71)$ & $(118)$ & $(68)$ & $(122)$ & $(56)$ & $(136)$ \\
& 52.2 & 86.8 & 50.0 & 90.4 & 41.2 & 100 \\
Sosyal & $(47)$ & $(69)$ & $(47)$ & $(61)$ & $(46)$ & $(78)$ \\
& 60.3 & 88.5 & 60.3 & 78.2 & 59.0 & 100 \\
\hline
\end{tabular}

\section{Güncel Gelişmeleri İzleme Yolları}

Öğretim üyelerinin alanlarıyla ilgili güncel gelişmeleri takip etmek için izledikleri yolların neler olduğu Tablo XII'de verilmektedir.

Tablo XII'ye göre tüm bilim alanlarındaki öğretim üyeleri, alanlarıyla ilgili mesleki gelişmeleri takip etmek için en çok internet ve elektronik ortamdan yararlanmaktadır. Fen bilimleri alanında çalışanların ikinci tercihleri alanlarıyla ilgili çevrimiçi taramalar yapmak iken; sağlık ve sosyal bilimler alanlarında çalışanların tercihleri ise bilimsel toplantıları izlemedir. Yayın kataloglarını izleme ise tüm bilim alanlarında en az tercih edilen yoldur.

Tablo XII. Öğretim Üyelerinin Güncel Gelişmeleri Takip Etme Yolları

\begin{tabular}{|c|c|c|c|c|c|c|c|c|}
\hline $\begin{array}{l}\text { Bilim } \\
\text { Dalları }\end{array}$ & $\begin{array}{l}\text { Meslektaşlarla } \\
\text { Bilgi Alış Veri- } \\
\text { şinde Bulunma }\end{array}$ & $\begin{array}{l}\text { Konunun } \\
\text { Uzmanlarıy- } \\
\text { la Görüşme }\end{array}$ & $\begin{array}{l}\text { Bilimsel } \\
\text { Toplantıla- } \\
\text { rı İzleme }\end{array}$ & $\begin{array}{l}\text { Basılı } \\
\text { Özleri ve } \\
\text { Dizinleri } \\
\text { Tarama }\end{array}$ & $\begin{array}{l}\text { Alanım- } \\
\text { la İlgili } \\
\text { Çevrim-İçi } \\
\text { Tarama } \\
\text { Yapma }\end{array}$ & $\begin{array}{l}\text { Yayın Ka- } \\
\text { taloglarını } \\
\text { İzleme }\end{array}$ & $\begin{array}{c}\text { İnternet ve } \\
\text { Elektronik } \\
\text { Ortamdan } \\
\text { Yararlanma }\end{array}$ & Toplam \\
\hline & (Sayı) & (Sayı) & (Sayı) & (Sayı) & (Sayı) & (Sayı) & (Sayı) & (Sayı) \\
\hline & $\%$ & $\%$ & $\%$ & $\%$ & $\%$ & $\%$ & $\%$ & $\%$ \\
\hline \multirow{2}{*}{ Sağlık } & (86) & (87) & (113) & (65) & (103) & (38) & (131) & (140) \\
\hline & 61.4 & 62.1 & 80.7 & 46.4 & 73.6 & 27.1 & 93.6 & 100 \\
\hline \multirow{2}{*}{ Fen } & (65) & (70) & (93) & (66) & (94) & (37) & (127) & (136) \\
\hline & 47.8 & 51.5 & 68.4 & 48.5 & 69.1 & 27.2 & 93.4 & 100 \\
\hline \multirow{2}{*}{ Sosyal } & (38) & (43) & (54) & (40) & (52) & (34) & (71) & (78) \\
\hline & 48.7 & 55.1 & 69.2 & 51.3 & 66.7 & 43.6 & 91.0 & 100 \\
\hline
\end{tabular}




\section{Yayın Dili Sorunları ve Tercihleri}

Öğretim üyelerinin bilgi aramalarında karşılaştıkları yayın dili sorunlarını ortaya koyan veriler Tablo XIII'dedir.

Tablo XIII. Öğretim Üyelerinin Bilgi Aramada Karşılaştıkları Dil Sorunları

\begin{tabular}{|c|c|c|c|c|c|c|}
\hline \multirow{3}{*}{$\begin{array}{l}\text { Bilim Dalları } \\
\begin{array}{l}\text { Yabancı Dil } \\
\text { Sorunu }\end{array}\end{array}$} & \multicolumn{2}{|c|}{$\begin{array}{c}\text { Sağlık } \\
\text { (Sayı) } \\
\% \\
\end{array}$} & \multicolumn{2}{|c|}{$\begin{array}{c}\text { Fen } \\
\text { (Sayı) } \\
\% \\
\end{array}$} & \multicolumn{2}{|c|}{$\begin{array}{c}\text { Sosyal } \\
\text { (Sayı) } \\
\% \\
\end{array}$} \\
\hline & Sorunu & Sorunu & Sorunu & Sorunu & Sorunu & Sorunu \\
\hline & Olanlar & Olmayanlar & Olanlar & Olmayanlar & Olanlar & Olmayanlar \\
\hline (Sayı) & (18) & (122) & (21) & (115) & (35) & (43) \\
\hline$\%$ & 13.2 & 86.8 & 15.4 & 84.6 & 44.9 & 55.1 \\
\hline Toplam & \multicolumn{2}{|c|}{ (140) } & \multicolumn{2}{|c|}{ (136) } & \multicolumn{2}{|c|}{ (78) } \\
\hline$\%$ & \multicolumn{2}{|c|}{100} & \multicolumn{2}{|c|}{100} & \multicolumn{2}{|c|}{100} \\
\hline
\end{tabular}

Tablo XIII'e göre, bilim dalları arasında en çok (\%44.9) yabancı dil sorunu yaşayanlar sosyal bilim alanında çalışanlardan oluşmaktadır. Sağlık ve fen bilimleri alanlarında çalışan öğretim üyelerinin büyük çoğunluğu dil sorunu yaşamamaktadır.

Öğretim üyelerinin bilgi aramalarındaki yayın dili tercihlerine yönelik veriler ise Tablo XIV'te verilmiştir.

Tablo XIV'e bakıldığında, sağlık ve fen bilimleri alanlarında çalışan öğretim üyelerinin bilgi aramada en çok yabancı yayın dilde yazı Imış yayınları tercih ederken; sosyal bilimler alanında çalışanlar ise daha çok Farsça yazılmış yayınları tercih etmektedirler. Sağlık ve fen bilimleri alanlarında çalışanlar azımsanmayacak düzeyde bilgi kaynağının yayın dilinin tercihlerini etkilemeyeceğini belirtmektedirler.

Tablo XIV. Öğretim Üyelerinin Bilgi Aramada Yayın Dili Tercihleri

\begin{tabular}{lccccc}
\hline \multirow{2}{*}{$\begin{array}{l}\text { Bilim } \\
\text { Dalları }\end{array}$} & $\begin{array}{c}\text { Kaynak Dilinin } \\
\text { Farsça Olması }\end{array}$ & $\begin{array}{c}\text { Yabancı Dilde } \\
\text { Yazılmış } \\
\text { Olması }\end{array}$ & $\begin{array}{c}\text { Kaynağın Farsçaya } \\
\text { Çevrilmiş Olması }\end{array}$ & $\begin{array}{c}\text { Kaynağın Yayın } \\
\text { Dili Tercihimi } \\
\text { Etkilemez }\end{array}$ & Toplam \\
\cline { 2 - 6 } & $\begin{array}{c}\text { (Sayı) } \\
\%\end{array}$ & $\begin{array}{c}(\text { Sayı) } \\
\%\end{array}$ & $\begin{array}{c}\text { (Sayı) } \\
\%\end{array}$ & $\begin{array}{c}\text { (Sayı) } \\
\%\end{array}$ & $\begin{array}{c}\text { (Sayı) } \\
\%\end{array}$ \\
\hline Sağlık & $(66)$ & $(88)$ & $(52)$ & $(82)$ & $(140)$ \\
& 47.1 & 62.9 & 37.1 & 58.6 & 100 \\
Fen & $(70)$ & $(89)$ & $(44)$ & $(55)$ & $(136)$ \\
& 51.5 & 65.4 & 32.4 & 40.4 & 100 \\
Sosyal & $(49)$ & $(44)$ & $(28)$ & $(25)$ & $(78)$ \\
\hline
\end{tabular}




\section{Bilgiye Erişim Sürecinde Karşılaşılan Sorunlar}

Öğretim üyelerinin bilgi erişim sürecinde karşılaştıkları sorunlara yönelik veriler Tablo $\mathrm{XV}$ 'te sunulmuştur.

Tablo XV. Öğretim Üyelerinin Bilgiye Erişim Sürecinde Karşılaştıkları Sorunlar

\begin{tabular}{lccc}
\hline & Sağlık & Fen & Sosyal \\
\cline { 2 - 4 } Sorunlar /Bilim Dalları & $\mathbf{( S a y ı )}$ & $($ Sayı) & (Sayı) \\
& $\%$ & $(55)$ & $(39)$ \\
\hline Gelişmelerden Haberdar Olma Zorluğu & $(60)$ & 40.4 & 50.0 \\
Kaynağının Kütüphanede Olmayışı & 42.9 & $(111)$ & $(75)$ \\
& $(127)$ & 81.6 & 96.2 \\
Yabancı Dil Sorunu & 90.7 & $(19)$ & $(22)$ \\
& $(30)$ & 14.0 & 28.2 \\
Uzman Kişilerin Yetersizliği & 21.4 & $(32)$ & $(29)$ \\
Bilimsel Toplantıların Yetersizliği & $(59)$ & 23.5 & 37.2 \\
Zaman Yetersizliği & 42.1 & $(24)$ & $(17)$ \\
Mali Kaynak Yetersizliği & $(49)$ & 17.6 & 21.8 \\
Bilgi Okuryazarlığının Olmayışı & 35.0 & $(30)$ & $(28)$ \\
Boplam & $(62)$ & 22.1 & 35.9 \\
& 44.3 & $(63)$ & $(26)$ \\
Internet Hızının Yetersizliği & $(48)$ & 46.3 & 33.3 \\
Bilgiye Erişme Güçlüğü Duymuyorum & 34.3 & $(25)$ & $(26)$ \\
\hline \multirow{2}{*}{ Makalelerin Elde Edilememesi } & $(44)$ & 18.4 & 33.3 \\
& 31.4 & $(4)$ & $(0)$ \\
& $(0)$ & 2.9 & 100 \\
\hline
\end{tabular}

Tablo XV'e göre, tüm bilim alanlarında çalışan öğretim üyelerinin bilgi erişim sürecinde karşılaştıkları en büyük sorun, bilgi kaynağının kütüphanede bulunmamasıdır. Sağlık bilimleri alanında çalışanlar için ikinci önemli sorun zaman yetersizliği iken; fen bilimleri alanında çalışanlar için mali kaynakların yetersizliği, sosyal bilimler alanında çalışanlar için ise güncel gelişmelerden haberdar olmanın zorluğudur. Bazı makalelerin elde edilememesi ve internet hızının yetersizliği ise tüm alanlarda en az karşılaşılan sorunlar arasında yer almaktadır. 


\section{Sonuç ve Öneriler}

İkinci Dünya Savaşı́ndan sonra bilgi üretiminin artışı ile bilgi ve iletişim teknolojilerindeki gelişmeler, kütüphanelerin politikalarının değişmesine ve kütüphanelerin bu teknolojilerden yararlanmasına neden olmuştur. Bilgi üreten ve kullanan kurumlar, yeni bir olayla yani bilgi devrimi ile karşı karşıya kalmıştır. Yeni meydana çıkan teknolojiler, görsel-işitsel ve metinsel bilginin düzenlemesine, saklanmasına, erişmesine ve paylaşılmasına yönelik yeni olanaklar sağlamış; tüm bu gelişmeler bilginin önemini daha da artırmıştır. Gündeme gelen yenilikler ve ilerlemeler, bireylerin ve toplumların davranışlarını ve özellikle de bilgi arama ve üretme davranışlarını etkilemiştir.

Bilimsel bilgiyi en çok üreten ve tüketenler öğretim üyeleridir. Üniversite kütüphaneleri, üniversitelerde görev yapan öğretim üyelerinin bilgi gereksinimlerinin karşılanmasında önemli bir rol üstlenmektedir.

Tebriz'deki üniversitelerde bulunan üniversite kütüphaneleri, öğretim üyelerinin bilgi gereksinimlerinin karşılamak ve iyi bir şekilde bilgi hizmeti sunabilmek için bu kitlenin özelliklerini, bilgi gereksinimlerini ve özellikle bilgi arama davranışlarını saptamak zorundadır.

Çalışma sonucunda bilgi ve iletişim teknolojileri etkisiyle Tebriz üniversitelerindeki kullanıcıların, kütüphaneleri mekânsal olarak kullanımlarında, geleneksel bilgi hizmetlerinden (danışma, kullanıcı eğitimi vb.) yararlanmalarında, basılı ortamdaki dermelerden yararlanmalarında düşüş yaşandığı buna karşın elektronik bilgi kaynaklarını kullanma sıklıklarının arttığı görülmektedir. Bu doğrultuda, söz konusu kullanıcı grubunun bilgi arama davranışlarının değiştiği söylenebilir.

Araştırma sonuçlarına dayanarak, Tebriz'deki üniversiteler başta olmak üzere üniversite kütüphanelerine yönelik şu öneriler sunulabilir:

1. Bilgi ve iletişim teknolojileri, kullanıcıların bilgi arama davranışlarını derinden etkilemektedir. Çeşitli kullanıcı gruplarının bilgi gereksinimleri ve bilgi arama davranışlarının ayrı ayrı incelenmesi, üniversite kütüphanelerinin bilgi hizmetleri politikası oluşturma sürecinde önemli rol oynayabilir.

2. Üniversite kütüphanelerinin kullanıcı gruplarının özelliklerini saptaması, bilgi ve iletişim teknolojilerinin sürekli etkilediği kütüphanelerin yeniden yapılanma süreçlerinde yararlı olabilir.

3. Bilgi ve iletişim teknolojilerinin araştırma ve öğrenme üzerine olan etkisi göz önüne alındığında, üniversite kütüphanelerinin bilgi hizmetlerini elektronik ortamlara taşımaları, ve bu ortamlara yönelik hizmetler geliştirmeleri gereklidir.

4. Bu bağlamda, kütüphanelerin varolan politikalarını gözdengeçirmeleri, kullanıcıların iş, öğrenme ve yaşam çevrelerinde daha etkin rol oynayabilmeleri için hizmetler ve politikalar yeniden şekillendirilmelidir.

5. Kullanııların, dijital ortamda sunulan yabancı dildeki bilgi kaynaklarından daha etkin yararlanabilmeleri için onlara sürekli yabancı dil ve bilgi okuryazarlığı eğitimi verilmelidir. 


\section{Kaynakça}

Arı, R., Üre, Ö. ve Yılmaz, H. (1999). Gelişim ve öğrenme psikolojisi (eğitimin psikolojik terimleri). Konya: Mikro Yayınları.

Başaran, İ. E. (2000). Örgütsel davranış: Insan üretim gücü. Ankara: Feryal Matbaası.

Baysal, C. ve Tekarslan, E. (2004). Işletmeciler için davranış bilimleri. İstanbul: Avciol.

Birkerts, S. (1994). The Gutenberg elegies: The fate of reading in an electronic age. Boston: Faber and Faber, MA.

Erdoğan, İ. (1994). Işletmelerde davranış. İstanbul: Beta Yayınevi.

Healy, J. M. (1990). Endangered minds: Why our children don't think. New York, NY: Simon and Schuster.

Kaygusuz, A. (2004). Değişen üniversite kütüphanelerinde kullanıcı ve kütüphaneci davranışı. Ü. Konya (Yay.Haz.). 40. Kütüphane Haftası Bildirileri. 29 Mart -6 Nisan 2004. içinde (ss.21-24). İstanbul: Türk Kütüphaneciler Derneği İstanbul Şubesi.

Liu, Z. (2005). Reading behavior in the digital environment: Changes in reading behavior over the past ten years. Journal of Documentation, 61(6), 700-712.

Ocholla, D. N. (1999). Insights into information-seeking and communicating behavior of academics. The International Information \& Library Review, 31(3), 119-143.

Uçak, N. Ö. (1999). Sosyal ve insan bilimleri alanlarında bilgi gereksinimi ve kullanımı. Hacettepe Üniversitesi Edebiyat Fakültesi Dergisi, 16(1), 115-128.

Soydan, S. (1979). Davranış bilimlerinde veri toplama teknikleri ve araştırma yapmanın güçlükleri. İstanbul Üniversitesi İşletme Fakültesi Pazarlama Dergisi, 4(3), 15.

Wilson, T. D. (1999). Models in information behaviour research. Journal of Documentation, 55(3), 249-270.

Wilson, T. D. (2000). Human information behaviour. Special Issue on Information Science Research, $3(2), 49-55$.

Yanbastı, G. (1996). Kişilik kuramları. İzmir: Ege Üniversitesi Edebiyat Fakültesi. 